\title{
Thiomicrospira kuenenii sp. nov. and Thiomicrospira frisia sp. nov., two mesophilic obligately chemolithoautotrophic sulfur- oxidizing bacteria isolated from an intertidal mud flat
}

\author{
Thorsten Brinkhoff, ${ }^{1}$ Gerard Muyzer, ${ }^{3}$ Carl O. Wirsen ${ }^{4}$ and Jan Kuever ${ }^{2}$
}

Author for correspondence: Jan Kuever. Tel: +49 4212028 734. Fax: +49 4212028580.

e-mail: jkuever@mpi-bremen.de

1,2 Molecular Ecology Group' and Department of Microbiology2,

Max-Planck-Institute for Marine Microbiology, Celsiusstraße 1, D-28359

Bremen, Germany

3 Netherlands Institute for Sea Research (NIOZ),

PO Box 59, NL-1790 AB

Den Burg (Texel),

The Netherlands

4 Department of Biology, Woods Hole Oceanographic Institution, Woods Hole MA 02543, USA
Two new members of the genus Thiomicrospira were isolated from an intertidal mud flat sample with thiosulfate as the electron donor and $\mathrm{CO}_{2}$ as carbon source. On the basis of differences in genotypic and phenotypic characteristics, it is proposed that strain JB-A1' (= DSM 12350') and strain JBA2 $^{\top}$ ( = DSM 12351') are members of two new species, Thiomicrospira kuenenii and Thiomicrospira frisia, respectively. The cells were Gram-negative vibrios or slightly bent rods. Strain JB-A1'T was highly motile, whereas strain JB-A2' showed a much lower degree of motility combined with a strong tendency to form aggregates. Both organisms were obligately autotrophic and strictly aerobic. Nitrate was not used as electron acceptor. Chemolithoautotrophic growth was observed with thiosulfate, tetrathionate, sulfur and sulfide. Neither isolate was able to grow heterotrophically. For strain JB-A1', growth was observed between pH values of 4.0 and 7.5 with an optimum at pH 6.0, whereas for strain JB-A2 ${ }^{\mathrm{T}}$, growth was observed between $\mathrm{pH} 4.2$ and 8.5 with an optimum at pH 6.5. The temperature limits for growth were between 3.5 and $42{ }^{\circ} \mathrm{C}$ and 3.5 and $39^{\circ} \mathrm{C}$, respectively. The optimum growth temperature for strain JB-A1 ${ }^{\top}$ was between 29 and $33.5^{\circ} \mathrm{C}$, whereas strain JB-A2 ${ }^{\top}$ showed optimal growth between 32 and $35^{\circ} \mathrm{C}$. The mean maximum growth rate on thiosulfate was $0.35 \mathrm{~h}^{-1}$ for strain $\mathrm{JB}-\mathrm{A} 1^{\top}$ and $0.45 \mathrm{~h}^{-1}$ for strain $\mathrm{JB}-\mathrm{A2}{ }^{\mathrm{T}}$.

Keywords: Thiomicrospira, sulfur-oxidizing bacteria, Wadden Sea

\section{INTRODUCTION}

The genus Thiomicrospira was first described by Kuenen \& Veldkamp (1972), who isolated the type species Thiomicrospira pelophila from the intertidal mud flats of the Dutch Wadden Sea. Since then, several other species have been isolated from different marine environments with a specific focus on deep-sea hydrothermal vents (Ruby \& Jannasch, 1982; Ruby et al., 1981; Jannasch et al., 1985; Wood \& Kelly, 1989; Eberhard et al., 1995). All members of this genus are obligately chemolithoautotrophic sulfur-oxidizing

Abbreviation: RuBisCO, ribulose-bisphosphate carboxylase.

The GenBank accession numbers for the 16S rRNA sequences of strains JB$A 1^{\top}$ and JB-A2 ${ }^{\top}$ are AF013978 and AF013974, respectively. bacteria. Heterotrophic growth of Thiomicrospira thyasirae (DSM 5322), as described by Wood \& Kelly $(1989,1993)$, was not reproducible during our studies (J. Kuever, unpublished results). Thiomicrospira spp. seem to play an important role in the re-oxidation of reduced sulfur compounds in marine habitats, but were also found in a freshwater habitat with high sulfide concentrations (Brinkhoff \& Muyzer, 1997). Except for Thiomicrospira denitrificans, all Thiomicrospira species isolated so far form a monophyletic group within the gamma subclass of the Proteobacteria (Muyzer et al., 1995; Brinkhoff \& Muyzer, 1997).

The aim of this study was to isolate new Thiomicrospira spp. from intertidal marine flats and get a better understanding of their ecological role in comparison to species isolated from deep-sea hydrothermal vent systems. 


\section{METHODS}

Culture media. The medium used for enrichments, isolation and routine culture work was liquid medium based on the medium for T. pelophila (TP) (Kuenen \& Veldkamp, 1972), with the exception that the trace element solution described by Widdel \& Bak (1992) was used. The medium was supplied with $20 \mathrm{mM}$ thiosulfate and bromothymol blue as a $\mathrm{pH}$ indicator. The initial $\mathrm{pH}$ of the medium was $7 \cdot 2$. Growth on single organic compounds and reduced sulfur sources was tested in TP medium without thiosulfate. For solid media, $1 \cdot 2 \%(\mathrm{w} / \mathrm{v})$ Difco Noble agar was added. A complex organic medium was used to determine general heterotrophic growth potential (Marine Broth 2216; Difco) and to detect possible heterotrophic contamination. Heterotrophic growth was tested for 8 weeks.

Isolation of bacteria. Enrichment cultures were obtained by inoculating $10 \mathrm{ml}$ medium with $0.1 \mathrm{~g}$ sediment from the Jadebusen area close to Sehestedt, Northern Germany, which belongs to the Wadden Sea of the North Sea. The cultures were incubated at $22^{\circ} \mathrm{C}$ in the dark to avoid growth of phototrophic bacteria. After growth was obtained, as indicated by a change in the colour of the $\mathrm{pH}$ indicator and by sulfur deposition, $0.1 \mathrm{ml}$ was transferred to $10 \mathrm{ml}$ fresh medium. For isolation of pure cultures $0.1 \mathrm{ml}$ of the enrichment cultures was transferred onto thiosulfate agar plates and repeatedly streaked out. Colonies were transferred at least three times to be considered pure. The isolates were differentiated by partial sequencing of the 16S rRNA gene obtained from several pure cultures, because the morphological features of the colonies were identical. $T$. pelophila (DSM 1534) and T. thyasirae (DSM 5322) were obtained from the Deutsche Sammlung für Mikroorganismen und Zellkulturen (DSMZ) (Braunschweig, Germany) and Thiomicrospira crunogena was kindly provided by $\mathbf{H}$. Jannasch.

Growth experiments. Batch cultures were grown in $500 \mathrm{ml}$ flasks containing $100 \mathrm{ml}$ medium on a rotary shaker at $22{ }^{\circ} \mathrm{C}$ in the dark. Routine cultivation of the isolates and utilization of different substrates were investigated in $15 \mathrm{ml}$ tubes containing $10 \mathrm{ml} \mathrm{TP}$ medium at 22 and $30^{\circ} \mathrm{C}$. Large-scale cultivation was done at $22^{\circ} \mathrm{C}$ in 31 and 201 glass carboys supplied with $40 \mathrm{mM}$ thiosulfate, in which the $\mathrm{pH}$ was monitored by a sterilized $\mathrm{pH}$ electrode (Ingold, Germany) and re-adjusted by titration with $\mathrm{Na}_{2} \mathrm{CO}_{3}(1 \mathrm{M})$ through a personal computer program controlling a peristaltic pump. The program was developed by Volker Meyer at the MaxPlanck-Institute for Marine Microbiology. The fermenter was aerated with sterile filtered pressurized air through sparkling devices.

The maximum growth rate in TP medium was determined at $30^{\circ} \mathrm{C}$ by direct counts (acridine orange staining and epifluorescence microscopy) (Hobbie et al., 1977), increase in optical density or protein concentration in $\mathrm{pH}$-controlled fermenters, and from the rate of $\mathrm{CO}_{2}$ incorporation, using $\mathrm{NaH}^{14} \mathrm{CO}_{3}$ (Wirsen et al., 1993; Eberhard et al., 1995; Tuttle \& Jannasch, 1977).

A rough estimate of the optimal $\mathrm{pH}$ value and the lowest and highest values tolerated by the isolates was determined by using TP medium adjusted to different initial $\mathrm{pH}$ values and supplied with $\mathrm{pH}$ indicators covering different $\mathrm{pH}$ ranges (bromocresol purple, 5.2-6.8; phenol red, 6.8-8.4; and thymol blue, $8 \cdot 0-9 \cdot 6$ ). Screening for acidification by a colour change of the $\mathrm{pH}$ indicator indicated growth. The optimal $\mathrm{pH}$ values for both isolates were determined by direct counts as indicated above. The $\mathrm{CO}_{2}$ incorporation rate was measured at the optimal $\mathrm{pH}$ and $0.5 \mathrm{pH}$ units above and below the optimum. The determination of the maximum growth rate under these conditions (Tuttle \& Jannasch, 1977; Wirsen et al., 1993) confirmed the optimal $\mathrm{pH}$ for growth. The lowest $\mathrm{pH}$ for growth was determined in a $\mathrm{pH}$-controlled 31 fermenter system.

The optimal growth temperature of the new isolates was determined in a thermally insulated aluminium block which was heated electrically to $+52.5^{\circ} \mathrm{C}$ at one end and cooled to $+3.5^{\circ} \mathrm{C}$ with a refrigerated circulation thermostat at the other end. The block contained 30 rows of four holes, so that samples could be incubated simultaneously at temperature intervals of $1.5^{\circ} \mathrm{C}$ with a maximum of four replicates. The temperature limits of growth were established by screening for acidification for $10 \mathrm{~d}$. The optimal growth temperature was determined within $24 \mathrm{~h}$ after inoculation.

The $\mathrm{Na}^{+}$requirement of the isolates was tested in TP medium supplied with $20 \mathrm{mM}$ thiosulfate containing various $\mathrm{Na}^{+}$concentrations $(40,57,83,100,140,290,470,640,1240$, $1580 \mathrm{mM}$ ) and incubated at $30^{\circ} \mathrm{C}$. All $\mathrm{Na}^{+}$concentrations included the sodium thiosulfate; increased concentrations were provided by addition of $\mathrm{NaCl}$.

Utilization of inorganic electron donors. The ability to oxidize and grow on different reduced sulfur compounds and formate was tested by using TP medium supplemented with one of the following compounds: thiosulfate $(20 \mathrm{mM})$, tetrathionate $(10 \mathrm{mM})$, sulfite $(3,5$ or $20 \mathrm{mM})$, thiocyanate $(3,5$ or $20 \mathrm{mM})$, elemental sulfur $(0 \cdot 1 \%, \mathrm{w} / \mathrm{v})$ or formate $(20$ or $40 \mathrm{mM})$. Growth on sulfide was determined by using $0.2 \%(\mathrm{w} / \mathrm{v})$ slush agar gradients over 8-mM-sulfide-containing agar plugs (Nelson \& Jannasch, 1983). Uninoculated controls showed no $\mathrm{pH}$ change and no turbidity.

Autotrophic growth on hydrogen was tested on solid mineral medium supplied with bicarbonate $(30 \mathrm{mM})$ incubated in a jar containing a gas mixture of $80 \% / 20 \%(\mathrm{v} / \mathrm{v})$ hydrogen/air and in liquid media (Drobner et al., 1990).

Formation of intermediate products. Formation of intermediates during growth on thiosulfate was monitored by cyanolysis (Kelly et al., 1969) and HPLC (Rethmeier et al., 1997).

Anaerobic growth. Whether nitrate was used as an electron acceptor in the absence of oxygen was tested under autotrophic and heterotrophic conditions by using bicarbonatebuffered $(30 \mathrm{mM}) \mathrm{TP}$ medium supplied with $20 \mathrm{mM} \mathrm{KNO}$ and prepared anaerobically. Hungate tubes contained $10 \mathrm{ml}$ liquid medium under a $90 \% / 10 \%(\mathrm{v} / \mathrm{v}) \mathrm{N}_{2} / \mathrm{CO}_{2}$ gas phase and the varied electron donors (see above). In addition, anaerobically prepared agar dilution series using the same electron donors as noted above were monitored for colony formation.

Utilization of organic electron donors. Heterotrophic growth was checked in TP medium without $\mathrm{pH}$ indicator supplied with one of the following compounds: fructose $(5 \mathrm{mM})$, glucose $(5 \mathrm{mM})$, acetate $(20 \mathrm{mM})$, pyruvate $(10 \mathrm{mM})$, lactate $(10 \mathrm{mM})$, Casamino acids $(0.1$ and $0.01 \%, \mathrm{w} / \mathrm{v})$, peptone $(0.1$ and $0.01 \%, \mathrm{w} / \mathrm{v})$ and yeast extract $(0.1$ and $0.01 \%$, $\mathrm{w} / \mathrm{v})$. The same additions in TP medium with bromothymol blue containing $20 \mathrm{mM}$ thiosulfate were used for testing for an inhibitory effect of organic compounds on thiosulfate oxidation.

Ubiquinone analysis. The ubiquinone fraction was isolated, purified and identified by B. J. Tindall (DSMZ Identification 
Two new sulfur-oxidizing Thiomicrospira spp.

Service, Braunschweig, Germany) from cells harvested from large-scale incubations. Respiratory lipoquinones were extracted from $100 \mathrm{mg}$ freeze-dried cell material using the twostage method described by Tindall (1990a, b). The lipoquinones were separated into their different classes by TLC (Macherey-Nagel no. 805 203), using hexane:tert-butyl methyl ether as solvent $(9: 1)$. UV-absorbing bands corresponding to ubiquinones were removed from the plate and further analysed by HPLC. The latter was carried out on an LDC Analytical (Thermoseparation products) HPLC apparatus fitted with a reverse-phase column (MachereyNagel, $2 \mathrm{~mm} \times 125 \mathrm{~mm}, 3 \mu \mathrm{m}$, RP18). Methanol served as eluant. Respiratory lipoquinones were detected at $269 \mathrm{~nm}$.

DNA base composition. For determining the $\mathrm{G}+\mathrm{C}$ content, cells were disrupted and the DNA was purified on hydroxyapatite (Cashion et al., 1977). The DNA was hydrolysed with P1 nuclease and the nucleotides were dephosphorylated with bovine alkaline phosphatase (Mesbah et al., 1989). The resulting deoxyribonucleosides were analysed by HPLC according to Tamaoka \& Komagata (1984). The instrument was calibrated with non-methylated lambda-DNA (Sigma), $\mathrm{G}+\mathrm{C}$ content $49.86 \mathrm{~mol} \%$. The $\mathrm{G}+\mathrm{C}$ content was calculated from the ratio of deoxyguanosine $(\mathrm{dG})$ and deoxyadenosine (dA) (Mesbah et al., 1989).

DNA-DNA hybridization. The DNA-DNA hybridizations were carried out by J. Burghardt (DSMZ, Braunschweig, Germany). The DNA was isolated as described above and the hybridization was carried out as described by De Ley et al. (1970) with the modifications described by Huß et al. (1983), using a Gilford System 2600 spectrophotometer equipped with a Gilford 2527-R thermoprogrammer and plotter. Renaturation rates were computed with the TRANSFER.BAS program (Jahnke, 1992).

Preparation of cell-free extracts. Cells were harvested from late-exponential growth phase and passed three times through a French press (extrusion pressure $49 \mathrm{MPa}$ ). Breakage of the cells was monitored by phase-contrast microscopy. Cell debris was removed by centrifugation and the supernatant was used for further experiments.

Enzyme assays. The ribulose-bisphosphate carboxylase $(\mathrm{RuBisCO})$ activity in the cell-free extracts was measured at $30^{\circ} \mathrm{C}$ according to the procedure of Beudeker et al. (1980) as modified by Nelson \& Jannasch (1983). An extract from spinach was used as a reference. Protein was determined by the Coomassie brilliant blue dye binding technique (Bradford, 1976) using a Bio-Rad protein assay kit.

Phylogenetic analysis. The $16 \mathrm{~S}$ rRNA sequences of strains JB-A1 ${ }^{\mathrm{T}}$ (Thiomicrospira kuenenii; GenBank accession no. AF013978) and JB-A2 ${ }^{\mathrm{T}}$ (Thiomicrospira frisia; GenBank accession no. AF013974) and the phylogenetic position were published previously (Brinkhoff \& Muyzer, 1997). In this paper we only show a similarity matrix of the $16 \mathrm{~S}$ rRNA sequences of all described Thiomicrospira spp. and closely related organisms.

\section{RESULTS}

\section{Isolation of strains $\mathrm{JB}^{\mathrm{A}-\mathrm{A}^{\top}}{ }^{\mathrm{T}}$ and $\mathrm{JB}-\mathrm{A} \mathbf{2}^{\mathrm{T}}$}

Subsequent to enrichment, pure cultures were obtained by subculturing single colonies and the two strains JB$\mathrm{A} 1^{\mathrm{T}}$ and $\mathrm{JB}-\mathrm{A} 2^{\mathrm{T}}$ were chosen for continued study. After the 16S rRNA genes had been sequenced and showed less than $96 \%$ similarity to all described
Thiomicrospira spp. and to each other (see Table 1) these cultures were used for further characterization.

\section{Morphology}

Cells of strain $\mathrm{JB}-\mathrm{A} 1^{\mathrm{T}}$ appeared as single motile vibrios of $0.3-0.4 \times 1 \cdot 0-2.5 \mu \mathrm{m}$ in size (Fig. 1a), whereas cells of $\mathrm{JB}-\mathrm{A} 2^{\mathrm{T}}$ were slightly bent rods of $0.3-0.5 \times 1.0$ $2 \cdot 7 \mu \mathrm{m}$ (Fig. 1b). Compared to JB-A1 ${ }^{\mathrm{T}}$ which was highly motile, strain $\mathrm{JB}-\mathrm{A} 2^{\mathrm{T}}$ showed a reduced level of motility. In the late-exponential growth phase, cells of strain JB-A $2^{\mathrm{T}}$ showed a tendency to clump, resulting in the formation of aggregates. Both isolates were Gramnegative and spore formation was absent.

\section{Growth conditions}

Both isolates are strictly aerobic and grow autotrophically on thiosulfate, tetrathionate, sulfur and sulfide, but not on sulfite and thiocyanate. Growth on thiosulfate lowered the $\mathrm{pH}$ to $3 \cdot 5$. Thiosulfate was completely oxidized to sulfate, with a recovery of 95 to $99 \%$. Formation of elemental sulfur was only observed on solid media, but not in liquid media. No growth occurred in TP medium supplemented with any of the organic substrates tested. The oxidation of thiosulfate was not inhibited by any of the organic substrates. Nitrate was not used as a terminal electron acceptor. Hydrogen was not used as an electron donor for autotrophic growth. Vitamin $\mathrm{B}_{12}$ was not essential for growth. Maximum growth rates on thiosulfate at $30^{\circ} \mathrm{C}$ and optimal $\mathrm{pH}$ were obtained from the mean of four different procedural determinations, i.e. $\mathrm{CO}_{2}$ incorporation, direct counts, optical density and protein production. The rate for strain $\mathrm{JB}-\mathrm{A} 1^{\mathrm{T}}$ was $0.35 \mathrm{~h}^{-1}$ (range $0 \cdot 3-0 \cdot 4 \mathrm{~h}^{-1}$ ), whereas strain $\mathrm{JB}-\mathrm{A} 2^{\mathrm{T}}$ showed a slightly higher rate of $0.45 \mathrm{~h}^{-1}$ (range $0.4-0.5 \mathrm{~h}^{-1}$ ). The rates were nearly the same for $100 \%$ and $20 \%$ airsaturated medium.

When the $\mathrm{pH}$ was re-adjusted to the optimal $\mathrm{pH}$ during growth on thiosulfate the new isolates showed no sulfur precipitation at all, whereas $T$. crunogena showed a strong precipitation. In cultures of strain JB$\mathrm{A} 1^{\mathrm{T}}$ and strain $\mathrm{JB}-\mathrm{A} 2^{\mathrm{T}}$ sulfur was detectable in very low concentrations of $200 \mu \mathrm{M}$ or below, and only at the end of the growth phase. Sulfite was only found at concentrations below $10 \mu \mathrm{M}$.

The $\mathrm{pH}$ range for growth on thiosulfate for strain JB$\mathrm{A} 1^{\mathrm{T}}$ was between 4.0 and $7 \cdot 5$. Above a $\mathrm{pH}$ of 7.5 no growth was observed. At a $\mathrm{pH}$ of 7.5 the lag phase was significantly extended. $\mathrm{CO}_{2}$ incorporation was found to be optimum at $\mathrm{pH} 6.0$, but at a $\mathrm{pH}$ of 5.5 and 6.5 the maximum growth rate was only slightly lower. Strain $\mathrm{JB}-\mathrm{A} 2^{\mathrm{T}}$ was able to grow between $\mathrm{pH} 4.2$ and 8.5 and showed an optimum $\mathrm{CO}_{2}$ incorporation at $\mathrm{pH} 6.5$. At a $\mathrm{pH}$ of 6.0 the maximum growth rate was slightly lower, whereas at a $\mathrm{pH}$ of 7.0 it showed a significant decrease.

For comparison we used $T$. pelophila and T. crunogena 
Table 1. 165 rDNA similarity values (\%) between strain JB-A $1^{\top}$, strain $\mathrm{JB}-\mathrm{A} 2^{\top}$ and related taxa of the gamma subclass of the Proteobacteria

The following accession numbers were used: Chromatium vinosum (M26629), Thiothrix nivea (M79435), Piscirickettsia salmonis (U36915), Bathymodiolus thermophilus (mussel) gill symbiont (M99445), Thiomicrospira pelophila (L40809), Thiomicrospira thyasirae (AF016046), Thiomicrospira crunogena (L40810), Thiomicrospira sp. L-12 (L01576), Thiomicrospira sp. MA2-6 (L40811), Thiomicrospira sp. JB-A1 ${ }^{\mathrm{T}}$ (AF013978) and Thiomicrospira sp. JB-A2 ${ }^{\mathrm{T}}$ (AF013974).

\begin{tabular}{|c|c|c|c|c|c|c|c|c|c|c|}
\hline & 1 & 2 & 3 & 4 & 5 & 6 & 7 & 8 & 9 & 10 \\
\hline \multicolumn{11}{|l|}{1 Chromatium vinosum } \\
\hline 2 Thiothrix nivea & $88 \cdot 5$ & & & & & & & & & \\
\hline 3 Piscirickettsia salmonis & $85 \cdot 2$ & $87 \cdot 1$ & & & & & & & & \\
\hline 4 Bathymodiolus thermophilus sym. & $85 \cdot 5$ & $86 \cdot 9$ & $84 \cdot 6$ & & & & & & & \\
\hline 5 Thiomicrospira pelophila & $84 \cdot 9$ & $84 \cdot 3$ & $83 \cdot 9$ & $86 \cdot 0$ & & & & & & \\
\hline 6 Thiomicrospira thyasirae & $85 \cdot 2$ & $84 \cdot 7$ & $84 \cdot 0$ & $85 \cdot 9$ & $99 \cdot 9$ & & & & & \\
\hline 7 Thiomicrospira crunogena & $84 \cdot 5$ & $84 \cdot 2$ & $85 \cdot 1$ & $85 \cdot 6$ & $92 \cdot 3$ & $92 \cdot 2$ & & & & \\
\hline 8 Thiomicrospira sp. L-12 & $84 \cdot 6$ & $84 \cdot 3$ & $84 \cdot 8$ & $85 \cdot 5$ & $91 \cdot 7$ & $91 \cdot 7$ & $99 \cdot 1$ & & & \\
\hline 9 Thiomicrospira sp. MA2-6 & $84 \cdot 7$ & $84 \cdot 8$ & $84 \cdot 5$ & $86 \cdot 1$ & $92 \cdot 5$ & $92 \cdot 5$ & $97 \cdot 2$ & $97 \cdot 1$ & & \\
\hline 10 Thiomicrospira $\mathrm{sp} . \mathrm{JB}-\mathrm{Al}^{\mathrm{T}}$ & $83 \cdot 9$ & $84 \cdot 4$ & $84 \cdot 9$ & $85 \cdot 4$ & $92 \cdot 1$ & $92 \cdot 1$ & $95 \cdot 6$ & $95 \cdot 7$ & $95 \cdot 0$ & \\
\hline 11 Thiomicrospira sp. JB-A2 & $83 \cdot 9$ & $84 \cdot 1$ & $84 \cdot 6$ & $85 \cdot 4$ & $91 \cdot 1$ & $91 \cdot 1$ & $94 \cdot 5$ & $94 \cdot 3$ & $93 \cdot 4$ & $94 \cdot 1$ \\
\hline
\end{tabular}
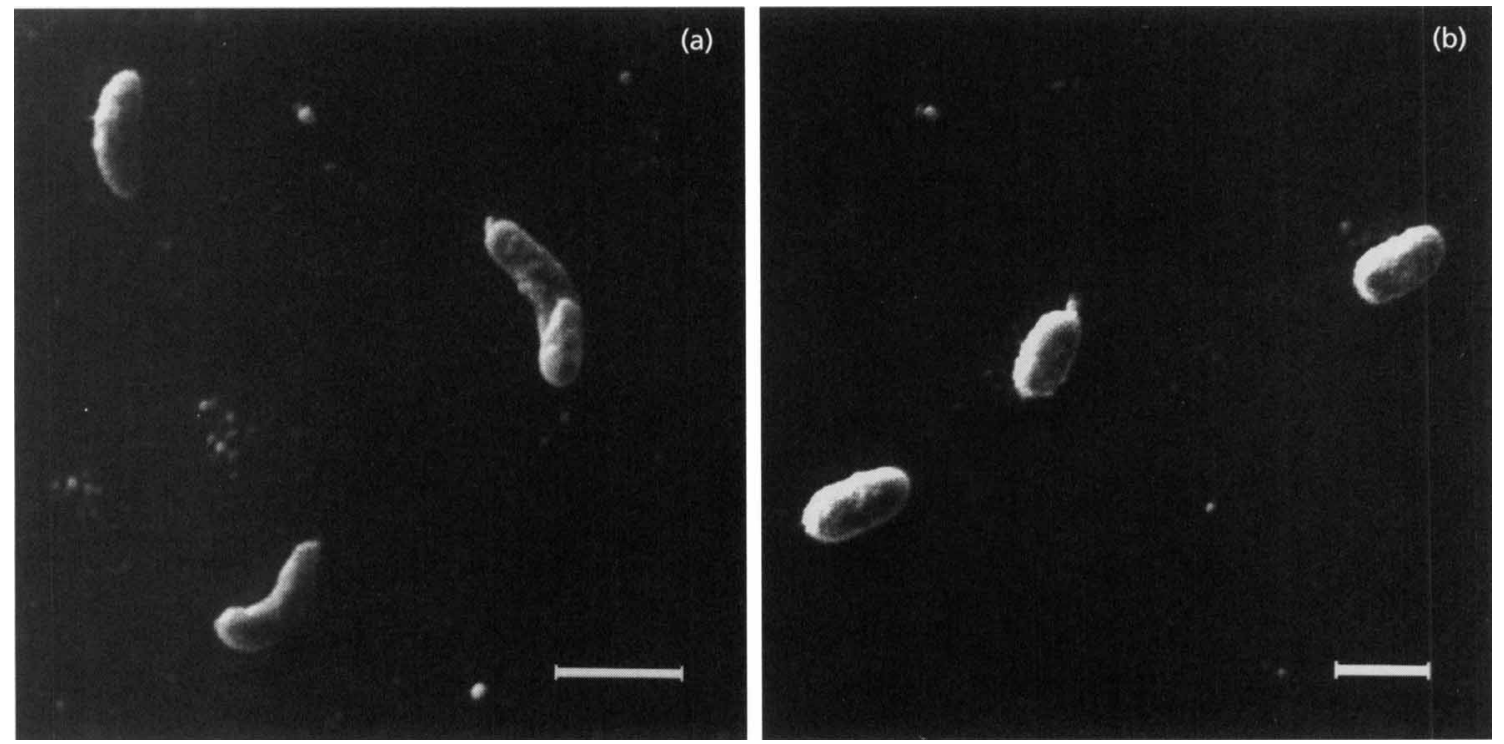

Fig. 1. Electron micrographs of both strains. (a) Typical morphology of strain $J B-A 1^{\top}$, very similar to all other described Thiomicrospira spp.; (b) typical rod-like morphology of strain JB-A2 ${ }^{\dagger}$, which is different to the other Thiomicrospira spp. Bars, $1 \mu \mathrm{m}$.

as reference strains. Both showed good agreement with previously published results (Kuenen \& Veldkamp, 1972; Jannasch et al., 1985). T. pelophila was even able to grow in medium with an initial $\mathrm{pH}$ of 9.0. Growth was monitored over a time period of 3 weeks.

The temperature ranges for growth were between 3.5 and $42{ }^{\circ} \mathrm{C}$ and 3.5 and $39^{\circ} \mathrm{C}$ for strain JB-A $1^{\mathrm{T}}$ and for strain JB-A2 ${ }^{\mathrm{T}}$, respectively, although growth below $3.5^{\circ} \mathrm{C}$ may proceed very slowly. The optimum growth temperature for strain JB-A1 ${ }^{\mathrm{T}}$ was between 29 and $33.5^{\circ} \mathrm{C}$, whereas strain $\mathrm{JB}-\mathrm{A} 2^{\mathrm{T}}$ showed optimal growth between 32 and $35^{\circ} \mathrm{C}$. Growth was determined by acidification of the medium over a period of $10 \mathrm{~d}$.

Both isolates showed a requirement for $\mathrm{Na}^{+}$which could not be satisfied by a substitution of $\mathrm{K}^{+}$. Strain $\mathrm{JB}-\mathrm{A} 1^{\mathrm{T}}$ was able to grow at a $\mathrm{Na}^{+}$concentration between 100 and $640 \mathrm{mM}$, whereas strain $\mathrm{JB}-\mathrm{A} 2^{\mathrm{T}}$ showed growth between 100 and $1240 \mathrm{mM}$. For both isolates a Na${ }^{+}$concentration of $470 \mathrm{mM}$ resulted in the best growth, although strain $\mathrm{JB}-\mathrm{A} 1^{\mathrm{T}}$ showed similar rates between 140 and $470 \mathrm{mM}$. For $T$. pelophila which was used as reference strain in this experiment, 
Two new sulfur-oxidizing Thiomicrospira spp.

Table 2. Levels of DNA-DNA similarity for Thiomicrospira spp.

\begin{tabular}{|c|c|c|c|}
\hline \multirow[t]{2}{*}{ Organism } & \multicolumn{3}{|c|}{ Homology (\%) } \\
\hline & T. pelophila & T. crunogena & T. kuenenii (JB-A1 $\left.{ }^{\mathrm{T}}\right)$ \\
\hline T. pelophila & $100 \cdot 0$ & & \\
\hline T. crunogena & $33 \cdot 5$ & $100 \cdot 0$ & \\
\hline T. kuenenii $\left(\mathrm{JB}-\mathrm{Al} 1^{\mathrm{T}}\right)$ & $25 \cdot 0$ & $29 \cdot 3$ & $100 \cdot 0$ \\
\hline T. frisia $\left(\mathrm{JB}-\mathrm{A} 2^{\mathrm{T}}\right)$ & $27 \cdot 0$ & $27 \cdot 0$ & $25 \cdot 0$ \\
\hline
\end{tabular}

reproducible growth was detectable at a $\mathrm{Na}^{+}$concentration as low as $40 \mathrm{mM}$, although the cells were very long and showed pleomorphism under these conditions as described previously (Kuenen \& Veldkamp, 1972; Wood \& Kelly, 1993). For T. crunogena growth was obtained in the same range as previously published (Jannasch et al., 1985).

\section{RuBisCO activity}

RuBisCO was found in cell-free extracts of both isolates. The specific activity for strain $\mathrm{JB}-\mathrm{A} 1^{\mathrm{T}}$ was $9.75 \mathrm{nmol} \mathrm{C}$ fixed (mg protein) ${ }^{-1} \mathrm{~min}^{-1}$, and strain JB$\mathrm{A} 2^{\mathrm{T}}$ showed a specific activity of $12.65 \mathrm{nmol} \mathrm{C}$ fixed (mg protein $)^{-1} \mathrm{~min}^{-1}$. Values for $T$. pelophila and $T$. crunogena were in a similar range and agreed well with previously published data (Kuenen \& Veldkamp, 1973).

\section{DNA base ratio and ubiquinone content}

The $\mathrm{G}+\mathrm{C}$ content was $42 \cdot 4 \pm 0 \cdot 2 \mathrm{~mol} \%$ for strain JB$\mathrm{A} 1^{\mathrm{T}}$ and $39 \cdot 6 \pm 0 \cdot 4 \mathrm{~mol} \%$ for strain $\mathrm{JB}-\mathrm{A} 2^{\mathrm{T}}$. Both isolates contained Q-8 as the major ubiquinone and small traces of ubiquinone Q-7.

\section{Phylogenetic analysis and DNA-DNA hybridization}

The similarity matrix values and the results of the DNA-DNA hybridization are shown in Tables 1 and 2 , respectively. Comparison of the nearly complete $16 \mathrm{~S}$ rRNA genes shows that strain JB-A $1^{\mathrm{T}}$ has at least a $4 \%$ difference and JB-A $2^{\mathrm{T}}$ has at least a $5 \%$ difference to all other described Thiomicrospira spp. The level of DNA-DNA hybridization between the different Thiomicrospira strains shown in Table 2 gives values of less than $30 \%$ for $\mathrm{JB}-\mathrm{A} 1^{\mathrm{T}}$ and $\mathrm{JB}-\mathrm{A} 2^{\mathrm{T}}$.

\section{DISCUSSION}

The isolates, strain $\mathrm{JB}-\mathrm{A} 1^{\mathrm{T}}$ and strain $\mathrm{JB}-\mathrm{A} 2^{\mathrm{T}}$, are both chemolithoautotrophic sulfur-oxidizing bacteria belonging to the genus Thiomicrospira. The similarity values of the 16S rRNA sequences for the new isolates as listed in Table 1 are below $97 \%$. According to the definition of Stackebrandt \& Goebel (1994) this already indicates that strain $\mathrm{JB}-\mathrm{A} 1^{\mathrm{T}}$ and strain $\mathrm{JB}-\mathrm{A} 2^{\mathrm{T}}$ do not belong to presently described species.
The level of DNA-DNA hybridization shown in Table 2 is far below the critical value of $70 \%$ (Wayne et al., 1987). In addition, as Table 3 shows, there are also significant physiological differences between the new isolates and the previously described species (for example: $\mathrm{pH}$ minimum, sulfur formation). Therefore, we propose that the isolates $\mathrm{JB}-\mathrm{A} 1^{\mathrm{T}}$ and $\mathrm{JB}-\mathrm{A} 2^{\mathrm{T}}$ be considered as two new species and be given the names Thiomicrospira kuenenii and Thiomicrospira frisia.

Table 3 also extends the description of this genus by adding some important biochemical data about the already described Thiomicrospira spp. which were so far not documented. An analysis of which ubiquinones are present in the respiratory chain of these organisms was rather incomplete.

When $T$. crunogena was cultivated with thiosulfate in liquid medium a strong precipitation of sulfur was observed which later was completely consumed and oxidized to sulfate, as previously described by Javor $e t$ al. (1990). At a $\mathrm{pH}$ below $7 \cdot 0$ this precipitation was even more obvious and sulfur oxidation was inhibited after the thiosulfate was completely consumed. We observed the same in our experiments with $T$. crunogena, but not for the new isolates. The latter formed no sulfur precipitation during growth on thiosulfate, even if the $\mathrm{pH}$ was not re-adjusted to the optimal value. In batch cultures without $\mathrm{pH}$ control very little sulfur was observed, but only at very low $\mathrm{pH}$ values. Therefore, we conclude that the metabolism of thiosulfate in our strains might be slightly different than in $T$. crunogena.

Another very interesting feature of both new isolates is the adaptation to lower $\mathrm{pH}$ values. This is also the case for $T$. pelophila which could also grow well at a $\mathrm{pH}$ lower than 6.5 (Kuenen \& Veldkamp, 1972; J. Kuever, unpublished results). This might be typical for sulfuroxidizing bacteria of tidal mud flats. In marsh muds, tidal flats or coastal sediments microenvironments of low pH are likely to exist (Jørgensen, 1977), whereas in deep-sea habitats the overlying water column brings a steady supply of well-buffered sea water with a more alkaline $\mathrm{pH}$. The higher optimal $\mathrm{pH}$ for growth of the Thiomicrospira spp. isolated from these habitats would imply such an adaptation.

If microzonations of low $\mathrm{pH}$ are present at tidal mud flats, $\mathrm{H}_{2} \mathrm{~S}$ would be released from the $\mathrm{FeS}$ as one dominant reduced sulfur compound in these habitats 
Table 3. Morphological and physiological characteristics among Thiomicrospira spp.

Data from Kuenen \& Veldkamp (1972, 1973); Kuenen \& Robertson (1989); Jannasch et al. (1985); and own data.

\begin{tabular}{|c|c|c|c|c|}
\hline Character & T. pelophila & T. crunogena & T. kuenenii $\left(\mathbf{J B}-\mathbf{A 1}^{\mathrm{T}}\right)$ & T. frisia $\left(\mathrm{JB}-\mathrm{A2}^{\mathrm{T}}\right)$ \\
\hline Shape & Vibrio & Vibrio & Vibrio & Rod \\
\hline Width $(\mu \mathrm{m})$ & $0 \cdot 2-0.3$ & $0 \cdot 4$ & $0 \cdot 3-0 \cdot 4$ & $0 \cdot 3-0 \cdot 5$ \\
\hline Length $(\mu \mathrm{m})$ & $1-2$ & $1 \cdot 5$ & $1 \cdot 0-2 \cdot 5$ & $1 \cdot 0-2 \cdot 7$ \\
\hline Motility & + & + & + & $+*$ \\
\hline $\mathrm{G}+\mathrm{C}$ content $(\mathrm{mol} \%)$ & $45 \cdot 7 \dagger(45)$ & $44 \cdot 4 \dagger(44)$ & $42 \cdot 4 \dagger$ & $39 \cdot 6 \dagger$ \\
\hline Ubiquinone & Q-8 & Q-8 & Q-8 & Q-8 \\
\hline Maximum growth rate $\left(\mathrm{h}^{-1}\right)$ & $0 \cdot 3$ & 0.8 & 0.35 & $0 \cdot 45$ \\
\hline Optimal pH & $7 \cdot 0 \ddagger$ & $7 \cdot 5-8 \cdot 0$ & 6.0 & 6.5 \\
\hline $\mathrm{pH}$ range & $5 \cdot 6-9 \cdot 0$ & $5 \cdot 0-8 \cdot 5$ & $4 \cdot 0-7 \cdot 5$ & $4 \cdot 2-8 \cdot 5$ \\
\hline Optimal temp. $\left({ }^{\circ} \mathrm{C}\right)$ & $28-30$ & $28-32$ & $29-33 \cdot 5$ & $32-35$ \\
\hline Temp. range $\left({ }^{\circ} \mathrm{C}\right)$ & $3 \cdot 5-42 \S$ & $4-38 \cdot 5$ & $3 \cdot 5-42 \S$ & $3 \cdot 6-39 \S$ \\
\hline Optimal $\mathrm{Na}^{+}$concn $(\mathrm{mM})$ & 470 & $\mathrm{ND}$ & 470 & 470 \\
\hline $\mathrm{Na}^{+}$concn range $(\mathrm{mM})$ & $40-1240 \|$ & At least 50 & $100-640$ & $100-1240$ \\
\hline Vitamin- $B_{12}$-dependent & + & - & - & - \\
\hline $\mathrm{RuBisCO}$ & + & + & + & + \\
\hline $\begin{array}{l}\text { Formation of sulfur from thiosulfate at } \mathrm{pH} \\
7.0 \text { in liquid medium }\end{array}$ & + & + & - & - \\
\hline
\end{tabular}

* Motility can rapidly decrease during growth.

† Determined by HPLC; values in parentheses were determined previously by thermal denaturation.

$\$$ Data from present study, determined by $\mathrm{CO}_{2}$ incorporation.

$\S$ Growth would be likely to occur below $3.6^{\circ} \mathrm{C}$.

$\|$ In medium without $\mathrm{NaCl}$ there was at least $20 \mathrm{mM} \mathrm{Na} \mathrm{S}_{2} \mathrm{O}_{3}$ present; cells of $T$. pelophila showed pleomorphism at low $\mathrm{Na}^{+}$ concentrations.

(Canfield \& Thamdrup, 1996). Because Thiomicrospira spp. and probably other sulfur-oxidizing bacteria acidify their environment, they might take direct advantage of this process by using the $\mathrm{H}_{2} \mathrm{~S}$ or its chemical oxidation products as electron donors, thus favouring this reaction by establishing a more acidic environment. If the sulfide is not directly consumed, other reduced sulfur compounds such as thiosulfate, polythionates, sulfur, sulfite and sulfate will be produced through chemical oxidation (Canfield \& Thamdrup, 1996; Zhang \& Millero, 1993). All these compounds, except sulfite and sulfate, are excellent substrates for growth of Thiomicrospira.

It has been demonstrated that deep-sea hydrothermal vent Thiomicrospira spp. can grow autotrophically while oxidizing various mineral sulfides at circumneutral $\mathrm{pH}$ (Eberhard et al., 1995). The optimal $\mathrm{pH}$ for growth on these mineral sulfides was found to be 6.5-7.0 compared to an optimal $\mathrm{pH}$ of 7.5 for growth on thiosulfate. This might indicate a slightly acidic $\mathrm{pH}$ optimum for growth on mineral sulfides. In terrestrial systems the maximum rate of dissolution for pyrite occurs between a pH of 1 and 5 (Schüring et al., 1997). An adaptation to lower $\mathrm{pH}$ values as it was found for the new Thiomicrospira spp. described in this paper may be an advantage in habitats rich in $\mathrm{FeS}$ and $\mathrm{FeS}_{2}$. These minerals should be considered as likely electron donors for Thiomicrospira spp. or other sulfur-oxi- dizing bacteria in sediments from the Wadden Sea. We were able to get very slow but reproducible growth of both isolates on FeS, but not on synthetic pyrite (J. Kuever, unpublished results).

\section{Description of Thiomicrospira kuenenii sp. nov.}

Thiomicrospira kuenenii (kue.nen'i.i. M.L. gen. n. kuenenii of Kuenen, named after J. G. Kuenen, a Dutch microbiologist of the Delft School of Microbiology, who proposed the genus Thiomicrospira).

Cells are Gram-negative, motile and vibrio-shaped $(0.3-0.4 \times 1.0-2.5 \mu \mathrm{m})$. T. kuenenii is strictly aerobic and grows autotrophically on thiosulfate, tetrathionate, sulfur and sulfide, but not on sulfite or thiocyanate. The organism does not grow heterotrophically. When thiosulfate is used as the primary energy source very small amounts of sulfur and sulfite are produced. Compared to other Thiomicrospira spp. sulfur precipitation in liquid medium is less obvious. During growth on reduced sulfur compounds the $\mathrm{pH}$ decreases from neutrality to around $3 \cdot 5$. Thiosulfate is completely oxidized to sulfate. Autotrophic growth on thiosulfate occurs between $\mathrm{pH} 4.0$ and 7.5 and at a temperature of $3.5-42{ }^{\circ} \mathrm{C}$; optimum growth occurs at $\mathrm{pH} 6.0$ and at $29-33^{\circ} \mathrm{C}$. The optimal $\mathrm{Na}^{+}$concentration for growth is $470 \mathrm{mM}$; growth is possible between $\mathrm{Na}^{+}$concentrations of 100 and $640 \mathrm{mM} . \mathrm{CO}_{2}$ 
is fixed by means of ribulose bisphosphate carboxylase. Nitrate is not used as terminal electron acceptor. On thiosulfate agar, cells produce white to yellowish, smooth, entire colonies (diameter on $1.2 \%, \mathrm{w} / \mathrm{v}$, agar is $2-5 \mathrm{~mm}$ ) in which sulfur is deposited and acid is produced. Ubiquinone Q-8 is present in the respiratory chain. The $\mathrm{G}+\mathrm{C}$ content of the DNA is $42 \cdot 4 \mathrm{~mol} \%$. As determined by a $16 \mathrm{~S}$ rRNA gene sequence analysis, $T$. kuenenii belongs to the gamma subclass of the Proteobacteria and is closely related to previously described members of the genus Thiomicrospira. The type strain of the species is JB-A $1^{\mathrm{T}}$ (= DSM $12350^{\mathrm{T}}$ ). The GenBank accession number for the nearly complete 16S rRNA gene sequence of $T$. kuenenii is AF013978.

\section{Description of Thiomicrospira frisia sp. nov.}

Thiomicrospira frisia (fri'.si.a. M.L. fem. adj. frisia pertaining to Frisia, a coastal region in the north-west of Germany and the Netherlands).

Cells are Gram-negative, motile and bent-rod shaped $(0.3-0.5 \times 1.0-2.7 \mu \mathrm{m})$. During late-exponential growth cells have a strong tendency to clump and to form aggregates. $T$. frisia is strictly aerobic and grows autotrophically on thiosulfate, tetrathionate, sulfur and sulfide, but not on sulfite or thiocyanate. The organism does not grow heterotrophically. When thiosulfate is used as the primary energy source small amounts of sulfur and sulfite are produced. During growth on reduced sulfur compounds the $\mathrm{pH}$ decreases from neutrality to around 3.5 . Thiosulfate is completely oxidized to sulfate. Autotrophic growth on thiosulfate occurs between $\mathrm{pH} 4.2$ and 8.5 and at a temperature of $3.5-39^{\circ} \mathrm{C}$; optimum growth occurs at $\mathrm{pH} 6.5$ and at $32-35^{\circ} \mathrm{C}$. The optimal $\mathrm{Na}^{+}$concentration for growth is $470 \mathrm{mM}$; growth is possible between a $\mathrm{Na}^{+}$concentration of 100 and $1240 \mathrm{mM}$. $\mathrm{CO}_{2}$ is fixed by means of ribulose bisphosphate carboxylase. Nitrate is not used as terminal electron acceptor. On thiosulfate agar, cells produce white to yellowish, smooth, entire colonies (diameter on $1.2 \%$, $\mathrm{w} / \mathrm{v}$, agar is $2-5 \mathrm{~mm}$ ) in which sulfur is deposited and acid is produced. Ubiquinone Q-8 is present in the respiratory chain. The $\mathrm{G}+\mathrm{C}$ content of the DNA is $39.6 \mathrm{~mol} \%$. As determined by a $16 \mathrm{~S}$ rRNA gene sequence analysis, $T$. frisia belongs to the gamma subclass of the Proteobacteria and is closely related to previously described members of the genus Thiomicrospira. The type strain of the species is $\mathrm{JB}-\mathrm{A} 2^{\mathrm{T}}(=$ DSM $12351^{\mathrm{T}}$ ). The GenBank accession number for the nearly complete $16 \mathrm{~S}$ rRNA gene sequence of $T$. frisia is AF013974.

\section{ACKNOWLEDGEMENTS}

The authors thank B. Braun, T. Heidorn, H. Jannasch, J. G. Kuenen, I. Kunze, J. Lüchtenborg, V. Meyer, J. Rethmeier, A. Teske and H. G. Trüper for advice and help. The project was supported by the Max-Planck-Society and also in part by the National Science Foundation grant OCE-9615830 awarded to C.O.W. This is contribution no. 9684 from the Woods Hole Oceanographic Institution.

\section{REFERENCES}

Beudeker, R. F., Cannon, G. C., Kuenen, J. G. \& Shively, J. M. (1980). Relations between D-ribulose-1,5-biphosphate carboxylase, carboxysomes and $\mathrm{CO}_{2}$ fixing capacity in the obligate chemolithotroph Thiobacillus neapolitanus grown under different limitations in the chemostat. Arch Microbiol 124, 185-189.

Bradford, M. M. (1976). A rapid and sensitive method for the quantitation of microgram quantities of protein utilizing the principle of protein-dye binding. Anal Biochem 72, 248-254.

Brinkhoff, T. \& Muyzer, G. (1997). Increased species diversity and extended habitat range of sulfur-oxidizing Thiomicrospira spp. Appl Environ Microbiol 63, 3789-3796.

Canfield, D. E. \& Thamdrup, B. (1996). Fate of elemental sulfur in an intertidal sediment. FEMS Microbiol Ecol 19, 95-103.

Cashion, P., Holder-Franklin, M. A., McCully, J. \& Franklin, M. (1977). A rapid method for the base ratio determination of bacterial DNA. Anal Biochem 81, 461-466.

De Ley, J., Cattoir, H. \& Reynaerts, A. (1970). The quantitative measurement of DNA hybridization from renaturation rates. Eur J Biochem 12, 133-142.

Drobner, E., Huber, H. \& Stetter, K. O. (1990). Thiobacillus ferrooxidans, a facultative hydrogen oxidizer. Appl Environ Microbiol 56, 2922-2923.

Eberhard, C., Wirsen, C. O. \& Jannasch, H. W. (1995). Oxidation of polymetal sulfides by chemolithoautotrophic bacteria from deep-sea hydrothermal vents. Geomicrobiol J 13, 145-164.

Hobbie, J. E., Daley, R. J. \& Jasper, S. (1977). Use of Nuclepore filters for counting bacteria by fluorescence microscopy. Appl Environ Microbiol 33, 1225-1228.

Huß, V. A. R., Festl, H. \& Schleifer, K. H. (1983). Studies on the spectrophotometric determination of DNA hybridization from renaturation rates. Syst Appl Microbiol 4, 184-192.

Jahnke, K.-D. (1992). BASIC computer program for evaluation of spectroscopic DNA renaturation data from GILFORD SYSTEM 2000 spectrophotometer on a PC/XT/AT type personal computer. J Microbiol Methods 15, 61-73.

Jannasch, H. W., Wirsen, C. O., Nelson, D. C. \& Robertson, L. A. (1985). Thiomicrospira crunogena sp. nov., a colorless sulfuroxidizing bacterium from a deep-sea hydrothermal vent. Int $J$ Syst Bacteriol 35, 422-424.

Javor, B. J., Wilmot, D. B. \& Vetter, R. D. (1990). pH-dependent metabolism of thiosulfate and sulfur globules in the chemolithotrophic marine bacterium Thiomicrospira crunogena. Arch Microbiol 154, 231-238.

Jørgensen, B. B. (1977). The sulfur cycle of a coastal marine sediment (Limfjorden, Denmark). Limnol Oceanogr 22, 814 832.

Kelly, D. P., Chambers, L. A. \& Trudinger, P. A. (1969). Cyanolysis spectrophotometric estimation of trithionate in mixture with thiosulfate and tetrathionate. Anal Chem 41, 898-901.

Kuenen, J. G. \& Robertson, L. A. (1989). Genus Thiomicrospira. Kuenen and Veldkamp 1972, 253 ${ }^{\mathrm{AL}}$. In Bergey's Manual of Systematic Bacteriology, vol. 3, pp. 1858-1861. Edited by J. T. Staley, M. P. Bryant, N. Pfennig \& J. G. Holt. Baltimore: Williams \& Wilkins.

Kuenen, J. G. \& Veldkamp, H. (1972). Thiomicrospira pelophila, gen. n., sp. n., a new obligately chemolithotrophic colourless sulfur bacterium. Antonie Leeuwenhoek 38, 241-256. 
Kuenen, J. G. \& Veldkamp, H. (1973). Effects of organic compounds on growth of chemostat cultures of Thiomicrospira pelophila, Thiobacillus thioparus and Thiobacillus neapolitanus. Arch Microbiol 94, 173-190.

Mesbah, M., Premachandran, U. \& Whitman, W. B. (1989). Precise measurement of the $\mathrm{G}+\mathrm{C}$ content of deoxyribonucleic acid by high-performance liquid chromatography. Int $J$ Syst Bacteriol 39, 159-167.

Muyzer, G., Teske, A., Wirsen, C. O. \& Jannasch, H. W. (1995). Phylogenetic relationships of Thiomicrospira species and their identification in deep-sea hydrothermal vent samples by denaturing gradient gel electrophoresis of 16S rDNA fragments. Arch Microbiol 164, 165-172.

Nelson, D. C. \& Jannasch, H. W. (1983). Chemoautotrophic growth of a marine Beggiatoa in sulfide-gradient cultures. Arch Microbiol 136, 262-269.

Rethmeier, J., Rabenstein, A., Langer, M. \& Fischer, U. (1997). Detection of traces of oxidized and reduced sulfur compounds in small samples by combination of different high-performance liquid chromatography methods. J Chromatogr A 760, 295-302.

Ruby, E. G. \& Jannasch, H. W. (1982). Physiological characteristics of Thiomicrospira sp. strain L-12 isolated from deep-sea hydrothermal vents. $J$ Bacteriol 149, 161-165.

Ruby, E. G., Wirsen, C. O. \& Jannasch, H. W. (1981). Chemolithoautotrophic sulfur-oxidizing bacteria from the Galapagos Rift hydrothermal vents. Appl Environ Microbiol 42, 317-342.

Schüring, J., Kölling, M. \& Schulz, H. D. (1997). The potential formation of acid mine drainage in pyrite-bearing hard-coal tailings under water-saturated conditions: an experimental approach. Environ Geol 31, 59-65.

Stackebrandt, E. \& Goebel, B. M. (1994). Taxonomic note: a place for DNA-DNA reassociation and 16S rRNA sequence analysis in the present species definition in bacteriology. Int $J$ Syst Bacteriol 44, 846-849.
Tamaoka, J. \& Komagata, K. (1984). Determination of DNA base composition by reversed-phase high-performance liquid chromatography. FEMS Microbiol Lett 25, 125-128.

Tindall, B. J. (1990a). A comparative study of the lipid composition of Halobacterium saccaravorum from various sources. Syst Appl Microbiol 13, 128-130.

Tindall, B. J. (1990b). Lipid composition of Halobacterium lacusprofundi. FEMS Microbiol Lett 66, 199-202.

Tuttle, J. H. \& Jannasch, H. W. (1977). Thiosulfate stimulation of microbial dark assimilation of carbon dioxide in shallow marine environments. Microb Ecol 4, 9-25.

Wayne, L. G., Brenner, D. J., Colwell, R. R. \& 9 other authors (1987). International Committee on Systematic Bacteriology. Report of the ad hoc committee on reconciliation of approaches to bacterial systematics. Int $J$ Syst Bacteriol 37, 463-464.

Widdel, F. \& Bak, F. (1992). Gram-negative mesophilic sulfatereducing bacteria. In The Prokaryotes, 2nd edn, vol. IV, pp. 3352-3378. Edited by A. Balows, H. G. Trüper, M. Dworkin, W. Harder \& K. H. Schleifer. New York: Springer.

Wirsen, C. O., Jannasch, H. W. \& Molyneaux, S. J. (1993). Chemosynthetic microbial activity at Mid-Atlantic Ridge hydrothermal vent sites. J Geophys Res 98, 9693-9703.

Wood, A. P. \& Kelly, D. P. (1989). Isolation and characterization of Thiobacillus thyasiris sp. nov., a novel marine facultative autotroph and the putative symbiont of Thyasira flexuosa. Arch Microbiol 152, 160-166.

Wood, A. P. \& Kelly, D. P. (1993). Reclassification of Thiobacillus thyasiris as Thiomicrospira thyasirae comb. nov. An organism exhibiting pleomorphism in response to environmental conditions. Arch Microbiol 159, 45-47.

Zhang, J.-Z. \& Millero, F. J. (1993). The products from the oxidation of $\mathrm{H}_{2} \mathrm{~S}$ in seawater. Geochim Cosmochim Acta 57, 1705-1718. 